\section{Electoral Manipulation Informationally on Hoax Production in 2019 Presidential and Vice Presidential Election in Indonesia}

Journal of Government and Political Issues Volume 1, Issue 2, November 2021 (87-99)

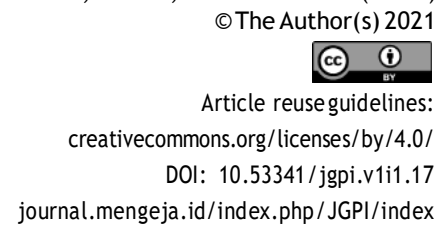

\author{
Wildhan Khalyubi ${ }^{1}$ (D) , Aditya Perdana
}

\begin{abstract}
This research aims to explain the hoax phenomenon with the concept of electoral manipulation in the form of information on the holding of 2019 Presidential and Vice Presidential General Election. Hoax problems in elections are often found in several countries such as Venezuela, France, the United States, and Indonesia. This research is qualitative research by combining primary and secondary data. Primary data was obtained through interview techniques with several institutions concerned about elections and hoaxes. Meanwhile, secondary data was obtained through literature, news, and documentation which support this research. As Alberto Simpser's view in this research expresses, electoral manipulation aims to increase the influence of groups of political actors on citizens as voters. Electoral manipulation was seen as a tool to win the upcoming elections and as a tool to influence people's behavior - elites, citizens, bureaucrats, organizations, politicians, and others - with excessive and blatant manipulation seeming logical. Therefore, this research found that by linking hoaxes as a form of informational electoral manipulation, it is found that hoaxes do not only attack political opponents. However, hoaxes as a part of electoral manipulation in the form of information have implications for efforts to delegitimize public trust in electoral organizers, especially the General Election Commission (KPU).
\end{abstract}

Keywords

electoral manipulation; hoax; presidential and vice-presidential election

\title{
Introduction
}

Manipulation and fraud in elections have generally been conceptualized about the ideal norm of liberal democracy, characterized by the popular idea of 'free and fair elections' which has also spread throughout the world, populist regimes with authoritarian tendencies such as Turkey, Russia, Hungary, or Brazil (Martin \& Picherit, 2020). Many forms of manipulation in elections were identified in three categories in elections, such as 1) fraud in the form of administrative, 2) manipulation that can mobilize the masses, and 3) intimidation of citizens as voters (Harvey \& Mukherjee, 2020).

Some of the literature on electoral manipulation is also much oriented to efforts to win elections, especially concerning the forms of electoral malpractice carried out by participants, organizers, and voters. Electoral institutions can also carry out electoral manipulation by preparing electoral laws and regulations to implement these arrangements, including manipulation in voting, counting, and tabulating (Ellis, 2012). In looking at the forms of electoral manipulation, the use of the electoral malpractice methodology found several things that could be manipulated such as how the electoral authorities independence, electoral registration, regulation and determination of polling stations, voting implementation, calculations and tabulations, restrictions on access by party agents, biased media coverage, campaign and financial resource issues, vote-buying, intimidation or barriers to the voter, and intimidation or blocking of candidates (Birch, 2011; Ellis, 2012). Several findings in this approach explain that electoral manipulation is more of a technical orientation that is manipulated, including the involvement of the organizers to win the electoral participants. Therefore in this view,

Corresponding author:

1 Wildhan Khalyubi, Master of Political Science, Universitas Indonesia, Indonesia.

Email: wildhan.khalyub@gmail.com 
electoral manipulation risks the credibility and independence of the organizers.

However, Schedler (2002) argues differently that electoral manipulation on fraudulent elections is not only about stuffing ballots. Therefore, in reality, electoral manipulation involves a whole "menu of manipulation" that includes a wide range of possible voter fraud acts to spread disinformation and prevent individuals and organizations from mobilizing to support parties or candidates. Schedler mentions this under the domain of what might be termed as a fraud of pre-vote (Javid \& Mufti, 2020). This view shows indirectly that how disinformation produces, especially in spreading hoax news, is a form of electoral manipulation in informational form. Therefore, whole information disturbance produced is a form of fraud that can be used as an indirect political effort to influence voters.

The view of Wardle \& Derakhshan (2017), which explains the concept of information manipulation, refers to an information disturbance such as a hoax and several things that include misinformation, mal-information, and disinformation. Hoax includes misinformation when false information was shared without intended harm. Meanwhile, disinformation is when false information is shared to cause harm. At the same time, mal-information is when truthful information is shared to cause harm, often by transferring information designed to stay private into the public domain. Wardle \& Derakhshan (2017) also add that over the years, politicians and business people have realized the potential for hoax news used for manipulation - politicians to achieve a specific position in society and business people for profit.

Several hoax phenomena classified as informational electoral manipulation also occur in several countries. Forelle et al. (2015); Ireton \& Posetti (2018) describe examples of cases experienced in Venezuela and France, two countries with manipulation in elections through the distribution of words contextualized with fake news. One phenomenon was the use of political bots elections when each narrative of political bots claimed to be part of the government in Venezuela (Forelle et al., 2015). Meanwhile, in France, Emmanuel Macron was attacked by a series of issues related to Saudi Arabia's funding of him ahead of election day, including the issue of hoaxes about illegal account openings in the Bahamas (Ireton \& Posetti, 2018).

Indonesia had an experience with the informational manipulation elections phenomenon in the holding of the president and vice-presidential elections in 2019. These phenomena were the several hoax cases that dragged electoral participants indirectly, for example, such as the case of Ratna Sarumpaet, who was allegedly assaulted at Bandung Airport (Gatra, 2018). This news had become a fuss in mass and social media until the political reaction in the election year emerged. Some reactions from that news, such as the day after the incident on the 3rd of October 2018, the Alumni Brotherhood (PA) 212 also commented on the alleged beating case that befell Ratna Sarumpaet was an inhumane case arguably barbaric (Prayoga, 2018). This false reporting case is a form of indirect informational electoral manipulation that can drag various parties to react to the actions received by Ratna Sarumpaet. That includes political actors members of the Prabowo-Sandi National Winning Front (BPN) campaign team such as presidential candidate Prabowo Subianto, Fahri Hamzah, Fadli Zon, and several other political actors.

Then the hoax case also attacked the electoral management authorities, the KPU. Mahsun \& Mufrikhah (2019) wrote that 35 confirmed politically oriented fake news cases attacked KPU institutions. Furthermore, these findings are classified into six types of findings of false news; 1 ) hoax related to fraudulent engineering by KPU; 2) hoaxes related to KPU servers; 3 ) hoaxes related to ballot logistics; 4) hoaxes related to DPT; 5) hoaxes related to voting; 6) hoaxes related to threats to commissioners with accusations of KPU's neutrality. One of these several classification problems of the hoax that attacks election organizers was the existence of false reports regarding seven containers of ballots imported from China with the conditions already punched. This allegation can harm the credibility of the election organizers and the political motives in question.

There were also cases of the hoax on behalf of the community as voters, namely news about plans for the deployment of large-scale demonstrations or it called by name people power in various places involving officials, as well as political actors, as well as carrying the name of ethnic identity (S. Gunawan, 2019). People power is a group of people who combine forces to achieve common goals, especially upholding justice and freedom (Ningsih, 2020). This discourse arose because of the rejection of the 2019 Presidential General Election result. In legal construction, people power can also be 
categorized as a form of political treason if it fulfills the elements of the Criminal Law such as planning where there is an intention to commit a criminal crime (Article 87), murder, or seizing independence, or nullifying how the ability of the President or Vice President to govern (Article 104), how the intention of separating all or part of the territory of the state (106), overthrowing the government (Article 107), releasing other territories or areas (139a), eliminating or illegally changing the form of state government (139b), and the loss of the life or independence of the king as arranged through planning or till death (Article 140).

The hoax content produced in the 2019 Presidential and Vice-Presidential Elections also has its own political goals. Generally, hoax content is produced and distributed to bring down each other's political opponents and supporters. Therefore, a condition of a polarized society such as in Indonesia produces political fake news content often carried out, especially by politicians and public figures for this purpose (Mahsun \& Mufrikhah, 2019).

This research looks at informational electoral manipulation in the context of the production hoaxes in the 2019 Presidential and Vice Presidential Elections in Indonesia. According to some researchers, the concept of electoral manipulation plays the role of information to deceive or make the recipients of information takes side with the manipulators. It is directly related to these efforts' goal to achieve victory in electoral contestation (Javid \& Mufti, 2020; Martin \& Picherit, 2020; Schedler, 2002). Some of the problems above illustrate the role of information in electoral contestation. The hoax phenomenon shows problems in electoral contestation; however, this questioning the role of information in the 2019 presidential and vice-presidential elections.

The case of hoaxes as false news occurred in the 2019 Presidential and Vice Presidential Elections that developed on social media. It was a new problem in the general election discourse. In looking at this phenomenon, the author integrates the form of false political news as a political hoax to the concept of informational electoral manipulation. This is based on the similarity in the forms of production or engineering of political discourse that can influence the recipients of messages to raise public opinion, especially those efforts that are considered political because it is an effort to win the political contestants by violating the rules agreed upon in the 2019 Presidential and Vice-Presidential Elections. This study tries to complete the novelty related to the hoax problem in electoral contestation to fill some previous studies. The focus of this research is that, among other things, hoaxes that are used informationally are directed at political opponents and against election administrators with various hoax problems encountered. Hoax as information can influence message readers, especially in growing distrust of the hoax object itself.

\section{Methods}

This research method is descriptive qualitative by looking at the hoax phenomenon in the presidential and vice-presidential election campaigns in 2019. A qualitative approach is an approach in which it applies methods to explore and understand the meaning that several individuals or groups of people consider to come from social or humanity problems (Creswell \& Creswell, 2017). However, it is necessary to look at the problem in-depth in exploring meaning.

Qualitative methods in looking at all problems in-depth require data collection techniques adjusted in this research. Data were obtained by combining primary and secondary data. Primary data was obtained through interviews with resource persons concerned about elections and hoaxes. Informants were also selected based on the background of civil society groups who were concerned in the field of election monitoring and hoaxes. In the field of election monitoring, the author interviewed Alwan Ola Riantoby as the National Coordinator of the Election Monitoring Network for the People (JPPR) to explore the issue of informational manipulation in the form of hoaxes as a problem in holding the elections. Meanwhile, the author also interviewed Eko Juniarto, as the Presidium of the Indonesian Anti-Defamation Society (Mafindo), which is also a representative of civil society concerned with the issue of hoaxes in Indonesia.

Meanwhile, secondary data was obtained through several studies of documentation following this research topic, in the form of literature, news, and problem data that the authors obtained. Secondary data was obtained through hoax findings, especially in the news after going through the mitigation process by Mafindo. The author saw several hoax reports through the turnbackhoax.id page, which 
resulted from Mafindo. Then the author analyzes through Nvivo12 Plus by looking at parties often targeted for hoax news in the 2019 presidential and vice-presidential elections.

\section{Result and Discussion}

Information manipulation, which was later referred to as part of a manipulation form, has become a problem in the electoral contestation in Indonesia. Information manipulation affects all electoral processes, especially in social media campaigns. Since the massive use of technology, this certainly has implications for changes in the forms, methods, and campaign arrangements in holding elections in 2019.

The differences in the underlying settings indicate this. For example, in the 2014 Presidential Election, the regulation regarding campaigning regulated more technically as in The Regulation of Electoral Commission (PKPU) Number 16 of 2014, which included several things such as 1) limited meetings, 2) face-to-face and dialogue, 3) dissemination through print and electronic media, 4) broadcasting through radio and/or television, 5) installation of props in public campaign places and other places determined by the KPU, 6) candidate's debate about campaign materials and 7) other activities that do not violate election campaign prohibitions and the provisions of laws and regulations. Meanwhile, in the 2019 General Election, the regulation regarding campaigning is widely regulated, including arrangements related to campaigns on social media as well as arrangements related to advertising facilities in print media, electronic media, and online media that will be funded by the KPU (Perdana \& Wildianti, 2018). The implication of the regulation regarding campaigns on social media also led to the need to register several media accounts for a maximum of 10 accounts used for campaigns, as stated in PKPU Number 23 of 2018 concerning Election Campaigns.

The widening of the campaign rules also has implications for vulnerability in campaigning on social media, specifically in the form of a ban on campaigning. This difference is explained in PKPU Number 16 of 2014, which explains that the prohibition on selling blocking segments, accepting sponsors, and selling advertising spots is only limited to print, online, and broadcasting mass media. However, in the 2019 Election, the prohibition rules expanded scope, including media in networks and social media as written in PKPU 23 of 2018 about Election Campaigns. However, the rules regarding campaigns on social media are considered unable to limit the spread of hoaxes on social media.

Because even though the campaign has been limited, problems regarding the spread of hoaxes will continue to be found (Cornelis, 2019). In this view, further regulation of social media is not regulated more clearly. Therefore, this creates a disconnected problem regarding campaigns and social media. The closure of social media accounts is also considered not to have been explained in detail, whether the phrase for closing social media accounts contained in the PKPU is limited to stopping the activation of social media accounts based on campaign content or being required to take down the account.

The regulation regarding the use of social media in elections is a step to suppress several violations in the election. However, social media can also threaten the existence of problems with the formation of anti-social actions and criminal behavior that can disturb the cyber community. Several forms of antisocial action and criminal behavior are also related to the implementation of elections, especially in the election of the President and Vice President, such as the phenomenon of the black campaign, which contains hoaxes and hates speech. This phenomenon is daily in social media spaces (Siregar, 2019). Parties are always not responsible for conducting a black campaign to support candidate pairs in every practice. This black campaign aims to divert public vote support as voters win the election contestation, especially in the presidential and vice-presidential elections (Sinaga, 2021).

\section{Hoax as Informational Electoral Manipulation}

Information engineering in the elections finds forms of vulnerability that could occur for any party. Informational electoral manipulation could be categorized as a problem often transformed into manipulative news or hoaxes. Therefore, this can affect the course of the contestation of the election. Simpser (2013) view states that electoral manipulation plays an informational role to increase influence on groups of political actors to citizens as voters. There are two main categories of information in electoral manipulation. First, manipulated information in elections might consist of expectations about the likelihood of eliciting a collective reaction from other social and political actors. Second, it 
concerns the attributes (capacity, resources, and disposition) of certain parties and parties who manipulate, which cannot be wholly or directly observable by the public but are relevant to the choice of actors.

Simpser's view can conclude that electoral manipulation could be done by conveying information that shapes the subsequent behavior of various political and social actors. In particular, electoral manipulation could influence behavior in two capacities: a coordinating tool and a source of information about the manipulator's attributes. Patterns of electoral manipulation vary widely due to the strategic choices of those who do it and the social and political actors who react to it. The essence of the argument is that electoral manipulation plays an informational role.

By sharing information and expectations about the power and prospects of political parties, electoral manipulation through such information can convincingly influence the behavior of various social and political actors. The informational nature of electoral manipulation increases what is at stake in the choice. Over-manipulating and/or overtly can convey or reinforce an image of power. Meanwhile, if it was deemed a failure in the effort to manipulate, it could project or reveal the weakness of the stronghold. Through this informational nature, Simpser (2013) asserts that electoral manipulation is seen not only as a tool to win the upcoming elections but also as a tool to influence the behavior of the people - elites, citizens, bureaucrats, organizations, politicians, and others - by excessive and blatant manipulation seems quite logical. In sum, electoral manipulation could alter or threaten to change any form of the electoral process. As explained above, this is further explained through an interview with Alwan Ola Riantoby as the National Coordinator of the JPPR, which is explained as follows:

"Hoax could be called as part of the manipulation of electoral information in the context of wanting to influence people to make choices. For example, campaign activities are defined as the process of presenting the program's vision and mission to influence people to vote for them. It is possible that information that is hoax or hate speech could be considered as a process of electoral manipulation or political manipulation to influence people with the aim they would vote for it." (Interview with Alwan Ola Riantoby, as JPPR National Coordinator, on the 26th of June 2021)

As there is an influence created through hoaxes, there are several implications of manipulation efforts in elections through the spread of political hoaxes. First, the hoax will be able to cause a commotion in the community so that it has the potential constructing public understanding regarding several things related to that information (Juliswara, 2017). The influence of exposure to political hoaxes will further lead to specific political attitudes in society. This also indirectly implies that the existence of hoaxes can negate the form of polarization caused by the noise. Second, manipulations in informational elections in political hoaxes can be used as opinion formation by using political symbols adapted to the spread of opinions (Sosiawan \& Wibowo, 2020). Political symbols adjusted to the desired opinion can be an attempt to attack certain individuals or groups. For these two reasons, the hoax has implications for creating hate speech that causes uproar in the community.

Informational electoral manipulation within hoaxes production is also a motive and purpose to shape public opinion. Morgan (2018) mentions deliberate attempts to gain economic and ideological gain. Furthermore, the hoax has become massive because there is an extraordinary concentration of power and economic income on the platform in the digital space. Through its concentration of power, the internet platform embodies the freedom of expression of social media users. Therefore, this creates dependence of social media users on the concentration of internet power (Morgan, 2018). Furthermore, economic motives and political ideology cannot be separated from political buzzers that of ten contest color. It is also explained further through the results of the author's interview with Eko Juniarto, as the Presidium of the Mafindo as follows:

The problem of manipulating hoaxes in informational elections is influencers or buzzers whose political affiliations are already visible. However, we do not know if he volunteered or if he was paid. However, most motives are based on economic motives to influence social media. Giving influence on social media is far from existing not only in electoral contestation, and this is indeed the standard of advertising how marketing is to manipulate people's psychological conditions. Therefore, it made the changing of society's thought from rational thought to impulsive thought." (Interview with Eko Juniarto, as the Presidium of Mafindo, on the 23rd of 
June, 2021).

Figure 1 explains the hoax production flow in the literature of Gunawan \& Ratmono (2018), which describes that hoax production begins with distrust, which is then continued through two production lines, namely political motives and economic motives. Political motives will be directly integrated with hate politics, while economic motives will be integrated with hate commodification. These two things are two variables of hoax production that can be viral to bring back public distrust. Therefore, this literature indirectly explains that hoaxes production always arises from public distrust and raises other public distrust.

Figure 1. The Hoax Production Flow

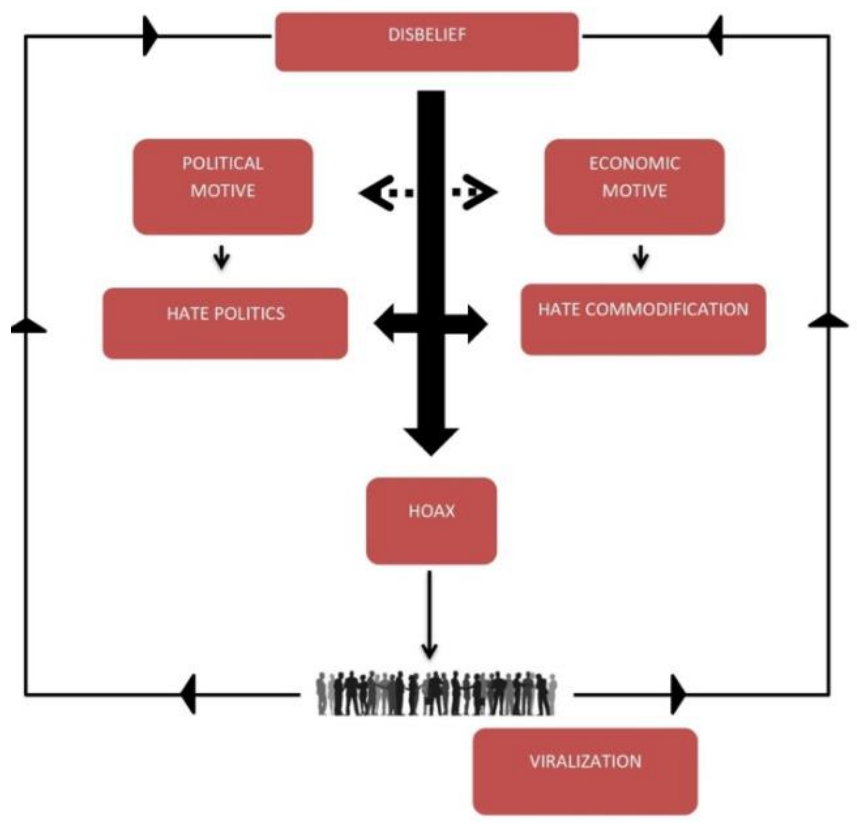

Source: B. Gunawan \& Ratmono (2018)

On the other hand, hoaxes are a form of dysfunction of the media, especially social media, which used to be a tool to make it easier to provide information for the users. However, the problem is where the spread of hoax news is not accompanied by the community's good supervision and literacy levels. Therefore that false information might often be used to form public opinion. As Balzacq, Leonard, and Ruzicka in Gunawan \& Ratmono (2018) state, dissemination of hoaxes in cyberspace is part of a political commodity, primarily related to the political escalation clash ahead of the election agenda. It was the case with several problems in the General Elections held concurrently in 2019. There were several political hoaxes found by the Ministry of Communication and Information (Kominfo) in the year the election was held, as explained in the following graph 1.

Graph 1 describes the Kominfo findings regarding hoaxes in the year 2019 when the election was held, with a total of 1,710 reports. This graph shows several data on hoaxes in the 2019 Concurrent Elections, especially from August 2018 to April 2019. The hoax increased every month, with an average increase of 51 reports. August to September was a period of stages that were considered more crucial. It was because, in addition to being the stage of drafting the Permanent Voter List (DPT), this month was also the stage of the registration period for the Presidential and Vice-Presidential Candidates, until the settlement of the dispute over the determination of the nominations for members of the Regional Representatives Council (DPD), the House of Representatives (DPR), the House of Regional Representatives (DPRD), and Presidential Candidates and Vice Presidential Candidates. 
Graph 1. Several Political Hoaxes in Concurrent Election in 2019

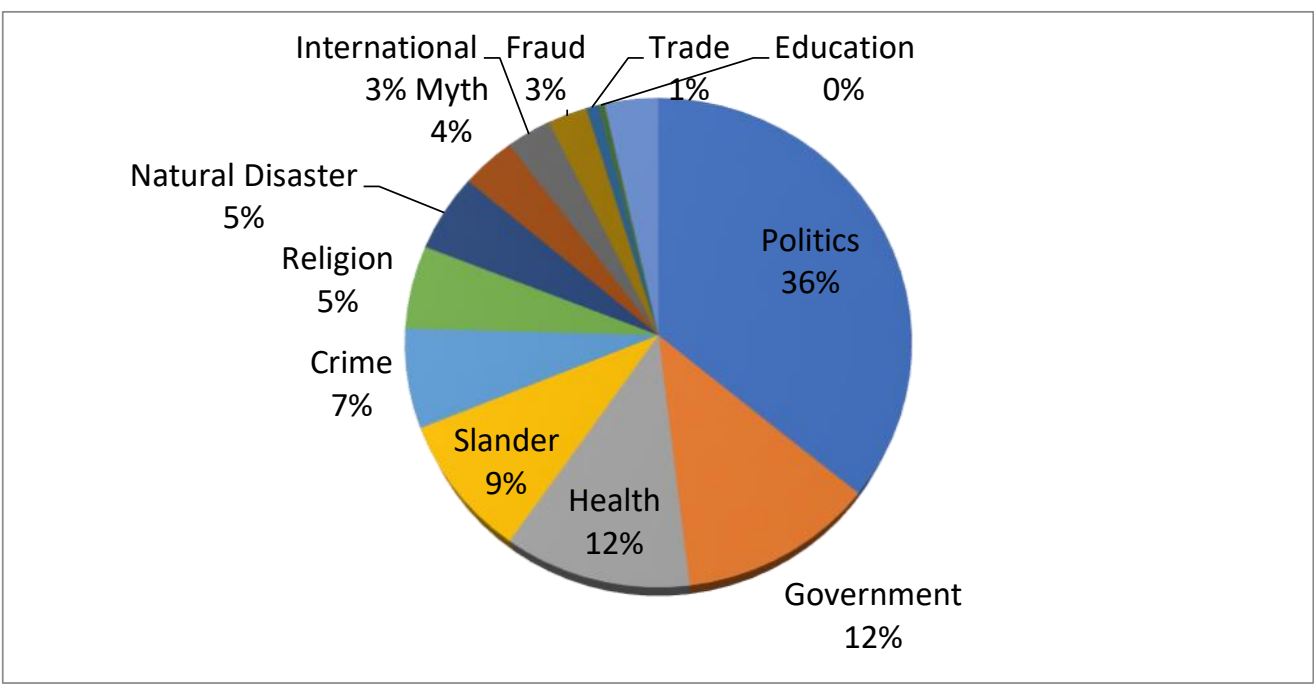

Source: Kominfo (2019)

In addition, the long duration of the campaign in the 2019 Presidential and Vice-Presidential Elections also triggered a high level of hoaxes in that year. The campaign is the desire to influence the beliefs and behavior of others with a communicative appeal (Paisley \& Rice, 2012). Therefore, in influencing and mobilizing the masses, hoaxes have become one of the political efforts, especially in the digital world, by supporters of candidate pairs. The campaign period was too long for 202 days stated in Law Number 7 of 2017 concerning Concurrent Elections. This campaign period starts from the 23rd of September 2018 until the 13th of April 2019. Therefore, following the graph above, it is found that most of the informational manipulation in the hoax production is present at the campaign stage, both the legislative candidate and the presidential and vice-presidential candidate election campaign. Then, to see several types of hoax in the year that held the election, it also explained as in the following graph:

\section{Graph 2. Types of Hoaxes in the 2019 Concurrent Elections}

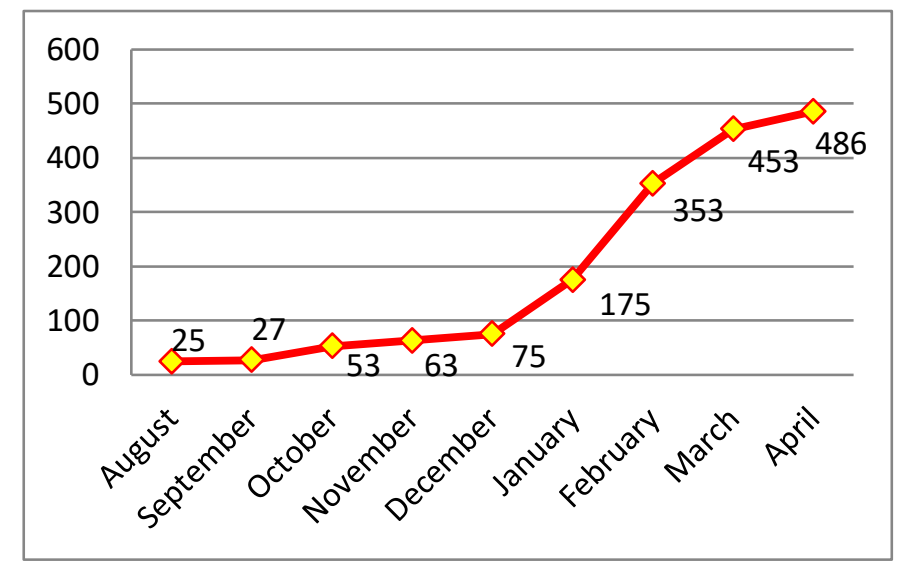

Source: Kominfo (2019)

Graph 2 shows that the most significant percentage of hoaxes was in the type of political hoax with $36 \%$. Then, it was followed by a hoax of government with a percentage of $12 \%$. Meanwhile, the type of hoax of health issues was in the following type with a percentage of $12 \%$. The several remaining types of hoax such as slander, crime, and religion were at a percentage below $10 \%$. The high level of hoaxes about politics was a new phenomenon in the election. In addition, the regulation regarding the long campaign period and the use of social media in the campaign also amplify hoaxes about politics among fellow users.

The role of information in the elections increased political problems with manipulative efforts. Hoaxes 
are part of an informational manipulative effort in holding elections in 2019. Furthermore, the hoaxes in the elections affect all the dynamics and contestations built in them. In social media, hoaxes are used to manipulate information in elections within forming public opinion in cyberspace.

\section{Parties who are Often Targeted with the Production of Hoaxes}

The vulnerability of hoaxes as part of an effort to manipulate elections in an informative manner has shifted the campaign process in a paradigmatic manner, which should have been carried out with the provisions and procedures contained in Law No. 7 of 2017 concerning Concurrent Elections along with PKPU as a derivative regulation. The spreading of hoaxes massively in the holding of the 2019 Presidential and Vice-Presidential Elections cannot be separated from various political efforts, one of which is the effort to co-opt election management institutions. This is explained by Eko Juniarto as the Presidium of Mafindo, as in the following interview:

"In 2009, the use of information technology in campaigning had the aim of still trying to change other people's choices. However, starting from the 2014 and 2019 elections, it has done more to co-opt the organizers, including circulating hoaxes. Even when the vote count in the election was in progress, the impact of using digital information was like trying to destabilize the situation; for example, there was information that would lead to riots" (interview with Eko Juniarto on the 23rd of June 2021).

There is a transformation of using digital in campaigning on every election agenda periodically. This shows the vulnerability of elections that occur, especially those that lead to a form of black campaign. The author tries to look at several cases of hoaxes during the presidential and vice-presidential election campaigns in 2019 by looking at the news originating from the turnbackhoax.id website during the campaign period from September 2018 to April 2019. This is explained in the following graph:

Graph 3. Parties Often Targeted with Hoaxes in 2019 Presidential and Vice Presidential Election

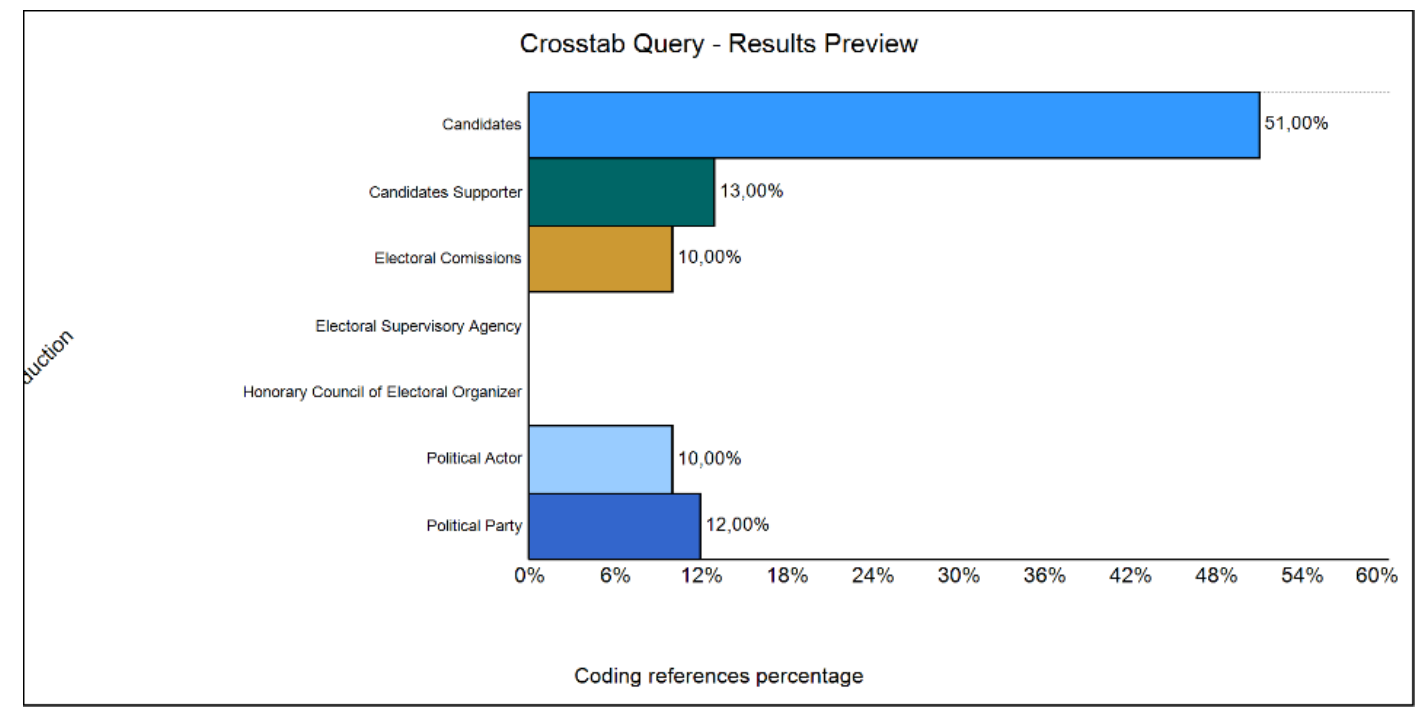

Source: data processed by the author using Crosstab Query Nvivo12 Plus through the turnbackhoax.id

Graph 3 explains that several parties are often targeted with a series of informational electoral manipulation in the production of hoaxes on 2019 Presidential and Vice-Presidential Election. The data were taken through Mafindo news on the turnbackhoax.id website. The distribution of the hoaxes has a lot to do with the candidates by $51 \%$, indicating that they are the parties most often targeted with the existence of hoaxes. Candidates, in this case, could be categorized as presidential and vicepresidential candidates such as Jokowi-Ma'ruf Amin or Prabowo-Sandiaga Uno. In addition, the supporters of each candidate ranked second with a percentage of $13 \%$. It cannot be separated from the contestation of the two candidates, who each have their supporters. Hoaxes related to political parties ranked third at $12 \%$. Many hoaxes that categorize certain political parties as foreign political parties such as PDIP and the Chinese Communist Party (PKC) or the issue of polygamy related to PKS are often found in every political campaign during the election. 
In addition, the effort to co-opt election management institutions is also evidenced by the presence of a hoax percentage of $10 \%$ against the KPU. Some of the news regarding the hoax issue against the KPU included none other than the issue of the KPU's neutrality towards one of the candidate pairs, ballot containers that had been punched, and foreigners registered in the Permanent Voters List (DPT). On the other hand, political actors also did not escape the hoax news during the campaign period with a percentage of $10 \%$.

Furthermore, the efforts to co-opt the election management institutions are mainly aimed at the KPU as a technical institution authorized to organize the election agenda. However, this is also not shown to several other election management institutions such as the General Elections Supervisory Agency (Bawaslu) and the Honorary Council of Electoral Organizer (DKPP). Both have a hoax engagement percentage below 1\%. The data in graph 3 indirectly shows that hoaxes as an informational manipulative effort in elections occurred massively and linked various parties such as election organizers, participants until candidate supporters who are the minor representation of the general electorate. As for the implications of the hoaxes existences as informational manipulation of the election to the organizers, it could have a negative effect on the community and will delegitimize the election results within the democratic process in Indonesia. Likewise, with the emergence of public distrust of the election process, especially the institutions responsible for holding elections (Sirait, 2020).

One of the problems with informational manipulation of elections in the form of hoaxes is the issue of hoaxes that link election organizers, especially in this case, targeted at the KPU. Mahsun \& Mufrikhah (2019) wrote that 35 confirmed politically oriented fake news cases attacked KPU institutions. Then the findings are further classified into six types of findings of false news; 1 ) hoax related to fraudulent engineering by KPU; 2) hoaxes related to KPU servers; 3) hoaxes related to ballot logistics; hoaxes related to DPT; 5) hoaxes related to voting; and 6) hoaxes related to threats to commissioners with accusations of KPU's neutrality. From these several classifications, one of the problems of hoaxes targeting election organizers is the existence of false news regarding seven containers of election ballots imported from China with the conditions already punched. This allegation can harm the credibility of the election organizers and the political motives in question.

The issue of the hoax case where the seven ballot containers were cast began with Andi Arief's tweet via the Twitter account @AndiArief_on Wednesday afternoon, the 2nd of January, 2019. Andi Arief tweeted the words, "Please check that there are reports that seven containers of ballots have been punched in Tanjung Priok. In order not to slander, please check the truth, because this news has been circulating," wrote Andi Arief (Siddiq, 2019). Then this tweet contained various reactions, especially from the KPU RI, who then rushed to find out the truth of the tweet.

The news of the seven containers of ballots that had been punched from China was explained by Ilham Saputra as the Commissioner of the Indonesian KPU (Septianto, 2019). First, Ilham explained that Andi Arief's tweet photo-documented the ballot distribution process in Kulon Progo, Yogyakarta. Second, the container with kanji letters belongs to the company that won the auction, namely PT. Temprina Media Graphics based in Solo, Central Java. Third, the veiled woman in the photo is the Chairperson of the Kulon Progo KPU, Ibah Mutiah.

The hoax carried out by Andi Arief belongs to linguistic manipulation, which later becomes a unit of information discourse in the election. Fahmi (2019) explained that the meaning of the text in the Andi Arief case was initially an appealing text. However, the problem is that the text is not accompanied by attaching facts. Therefore, the potential for being classified as fake news in elections is more tremendous because it is carried out on social media platforms that everyone can access.

On the other hand, the focus of informational manipulation in elections is the involvement of political actors. Andi Arief's hoax tweets became a concern during the 2019 presidential and vice-presidential election campaigns, inseparable from Andi Arief's position as a political actor. If it is contextualized into the production pattern chart described by B. Gunawan \& Ratmono (2018) in Figure 1, it explains that this distrust can be constructed mainly through political discourse by political actors to create hoaxes. Through its viral, hoax effort as information manipulation in this election can delegitimize election organizers in 2019. As the Saiful Mujani Research Center (SMRC) in Hui (2020) states, there are public doubts about the neutrality of the KPU in holding elections. This is indicated by the survey 
findings regarding public distrust of the KPU institution, which increased to $27-28$ percent.

Furthermore, from this explanation, it was found that informational manipulation of the election did not just appear. However, political elites such as Andi Arief also influenced the discourse construction efforts carried out. It can be said that this effort is indicated to delegitimize the election organizers with the resulting distrust as described in the hoax production flow in Figure 1.

Graph 4. Candidates Who Are Mostly as a Target of Spreading Hoaxes

Crosstab Query - Results Preview

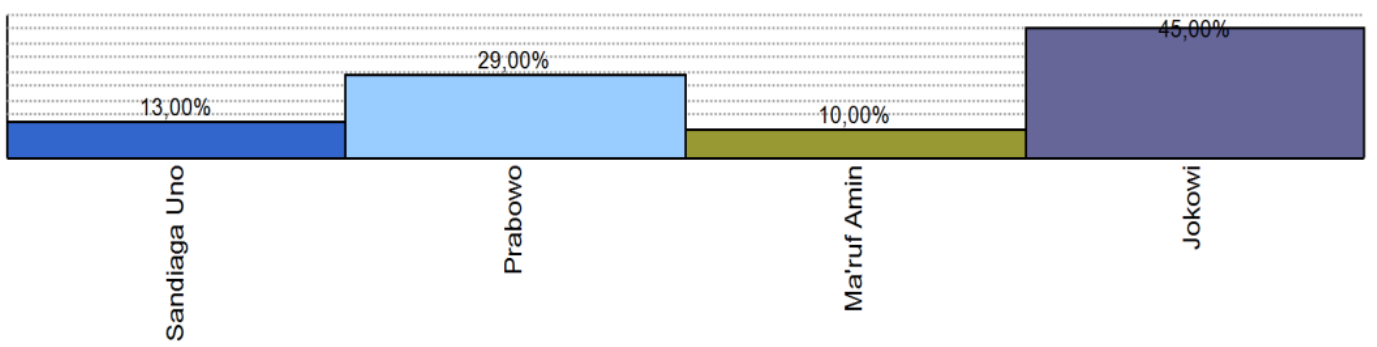

Source: data processed by the author using Crosstab Query Nvivo12 Plus through the Turnbackhoax.id

Furthermore, the author also deepens the analysis to see which candidates target manipulative efforts in election hoax information. In graph 4, the data were taken from Mafindo's news on the Turnbackhoax.id website. Jokowi has the highest percentage of $45 \%$ as a candidate who mainly targets hoax information. This is because Jokowi is the incumbent candidate as President of the Republic of Indonesia in the first period. Therefore, this makes it possible that Jokowi is the candidate who is often targeted and becomes the object of hoax in the 2019 presidential and vice-presidential election contestations.

Meanwhile, candidate Prabowo Subianto ranks second as a candidate mainly as a target of hoax information with a percentage of $29 \%$. This is also because Prabowo is a presidential candidate for the second time after also running in the 2014 election. In contrast to the presidential candidates, Sandiaga Uno and Ma'ruf Amin, vice presidential candidates, have a lower percentage than the presidential candidates, both Jokowi and Prabowo Subianto. Sandiaga Uno is mainly a target of hoax information with $13 \%$, while Ma'ruf Amin has a percentage of $10 \%$. This shows that hoax information mainly targets the two presidential candidates in the 2019 election.

The contestation of the presidential and vice-presidential elections in 2019 for each campaign carried out by the presidential and vice-presidential candidate pairs, be it Jokowi-Ma'ruf or Prabowo Sandi, is considered to use a firehose of falsehood. Informational election manipulation in the production of hoaxes is part of an effort to political propaganda on social media. The production of hoaxes in elections is believed to delegitimize the organizers, but hoaxes are also considered part of the firehose of falsehood propaganda technique.

Furthermore, what characterizes this effort is a hoax shifting the paradigm of how to campaign into a black campaign accompanied by a narrative of hatred towards objects, both political opponents and election organizers. This is, of course, close to the technical characteristics of using firehose of falsehood, which aims to influence the public, especially in the use of hoaxes during campaigning. One of the firehoses of falsehood propaganda arguments is manipulating language and information by bringing up emotions that do not make sense and are believed by most people (Haqqi, 2020).

\section{Conclusion}

As a part of informational manipulation of elections, Hoax has shown contemporary problems in contesting elections in 2019. Along with social media, information or news about elections spreads massively and rapidly. In particular, several attempts are often used to bring down political opponents, whether they are candidates, political parties, political actors, or supporters of each pair of candidates themselves. This effort is inseparable from economic motives and political, ideological motives. Although these two things are part of hoax production, another purpose of manipulating elections in an 
informative manner is to co-opt electoral organizers.

This research tries to look at the novelty by discussing the problem of hoaxes in elections associated with informational electoral manipulation. This research aims to conceptualize hoaxes as a form of informational election manipulation. So far, the meaning of this form of election manipulation has always revolved around budget abuse by incumbents, bureaucratic control, or the involvement of administrators at the ad-hoc level in vote counting. However, manipulation is also linguistic and relies heavily on information drawn from the political campaigns of candidates. Hoaxes are categorized as informational election manipulation and have implications for shifting the campaign into a black campaign with the firehose of falsehood technique to carry out propaganda against the recipients of information messages.

This study tries to expand the meaning of election manipulation by looking at the hoax case to manipulate information. One example of a hoax case that has ever circulated and targeted organizers as hoax objects in the election was the news about seven containers of ballots that were punched sent from China. The news involves political actors in constructing the discourse. Therefore, the pattern of hoax production as a form of manipulation of information in elections does not just appear, but there is a construction of a discourse of distrust of election organizers from political actors. Through this hoax, there is an attempt to co-opt the organizing agency, in this case, the KPU as the institution authorized to hold elections. This research found that by linking hoax as a form of informational electoral manipulation, it is found that hoax does not only attack political opponents. However, as electoral manipulation in information, hoaxes can delegitimize public trust to electoral organizers, especially the KPU. Although the percentage of hoaxes links electoral institutions, it is not too large compared to hoaxes against candidates.

\section{References}

Birch, S. (2011). Electoral Malpractice. Oxford: OxfordUniversity Press.

Cornelis, V. I. . (2019). Problematika Media Sosial Sebagai Sarana Kampanye Pemilu (Tinjauan Yuridis Pasal 275 Ayat 1e UU No. 7 Tahun 2017). Jurnal Kenegaraan, 1(2), 81-94.

Creswell, J. W., \& Creswell, J. D. (2017). Research Design: Qualitative, Quantitative, and Mixed Methods Approaches (5th ed.). London: Sage Publication. Retrieved from http://www.drbrambedkarcollege.ac.in/sites/default/files/Research-Design_Qualitative-

Quantitative-and-Mixed-Methods-Approaches.pdf

Ellis, A. (2012). The Cycle of Electoral Manipulation and its Links to Electoral Justice Systems. In Challenges to Electoral Integrity Pre-IPSA Workshop. Madrid, Spain: International Political Science Association. Retrieved from https://www.idea.int/sites/default/files/speeches/The-cycle-ofelectoral-manipulation-and-its-links-to-electoral-justice-systems-PDF.pdf

Fahmi, M. I. (2019). Kajian Hermeneutika Teks Pernyataan Andi Arief tentang Tujuh Kontainer Surat Suara Tercoblos di Twitter (Universitas Islam Negeri Sunan Ampel). Universitas Islam Negeri Sunan Ampel. Retrieved from http://digilib.uinsby.ac.id/33512/

Forelle, M. C., Howard, P. N., Monroy-Hernandez, A., \& Savage, S. (2015). Political Bots and the Manipulation of Public Opinion in Venezuela. SSRN Electronic Journal, 1-8. https://doi.org/10.2139/ssrn.2635800

Gatra, S. (2018). Ratna Sarumpaet Dikeroyok di Bandara Bandung. Retrieved July 20, 2021, from Kompas.com website: https://nasional.kompas.com/read/2018/10/02/13404631/ratnasarumpaet-disebut-dikeroyok-di-bandara-bandung?page=all

Gunawan, B., \& Ratmono, B. M. (2018). Kebohongan di Dunia Maya. Jakarta: KPG (Kepustakaan Populer Gramedia).

Gunawan, S. (2019). Aneka Hoax Pengerahan Massa Terkait People Power. Retrieved July 21, 2021, from JawaPos.com website: https://www.jawapos.com/hoax-atau-bukan/21/05/2019/anekahoax-pengerahan-massa-terkait-people-power/ 
Haqqi, A. (2020). Propaganda Firehose of Falsehood Pada Pemilu 2019 di Indonesia. WACANA: Jurnal Ilmiah Ilmu Komunikasi, 19(2), 175-185. https://doi.org/10.32509/.v19i2.1058

Harvey, C. J., \& Mukherjee, P. (2020). Methods of Election Manipulation and the Likelihood of PostElection Protest. Government and Opposition, 55(4), 534-556. https://doi.org/10.1017/gov.2018.38

Hui, J. Y. (2020). Social Media and the 2019 Indonesian Elections: Hoax Takes the Centre Stage. Southeast Asian Affairs, SEAA20(1), 155-174. https://doi.org/10.1355/aa20-1i

Ireton, C., \& Posetti, J. (2018). Journalism, Fake News \& Disinformation: Handbook for Journalism Education and Training. Paris. Retrieved from https: / / unesdoc.unesco.org/ark:/48223/pf0000265552

Javid, H., \& Mufti, M. (2020). Electoral Manipulation or Astute Electoral Strategy? Explaining the Results of Pakistan's 2018 Election. Asian Affairs: An American Review, 1-23. https://doi.org/10.1080/00927678.2020.1855033

Juliswara, V. (2017). Mengembangkan Model Literasi Media yang Berkebhinnekaan dalam Menganalisis Informasi Berita Palsu (Hoax) di Media Sosial. Jurnal Pemikiran Sosiologi, 4(2), 142. https://doi.org/10.22146/jps.v4i2.28586

Kominfo. (2019). Kominfo Temukan 3.356 Hoaks, Terbanyak saat Pemilu 2019. Retrieved July 20, 2021, from kominfo.go.id website: https://kominfo.go.id/content/detail/21876/kominfo-temukan3356-hoaks-terbanyak-saat-pemilu-2019/0/berita_satker

Mahsun, M., \& Mufrikhah, S. (2019). Serangan Hoax terhadap KPU pada Pemilu Serentak 2019 Studi di Jawa Tengah. Semarang. Retrieved from https://journal.kpu.go.id/index.php/ERE/issue/view/27

Martin, N., \& Picherit, D. (2020). Special Issue: Electoral Fraud and Manipulation in India and Pakistan. Commonwealth and Comparative Politics, Vol. 58, pp. 1-20. https://doi.org/10.1080/14662043.2020.1700016

Morgan, S. (2018). Fake News, Disinformation, Manipulation and Online Tactics to Undermine Democracy. Journal of Cyber Policy, 39-43. https: //doi.org/10.1080/23738871.2018.1462395

Ningsih, B. C. S. (2020). Tinjauan Yuridis Tindak Pidana Makar Pada Gerakan People Power Tanggal 17 April 2019. Dinamika: Jurnal Ilmiah Ilmu Hukum, 53(9), 869-881. Retrieved from http://riset.unisma.ac.id/index.php/jdh/article/view/5560

Paisley, W. J., \& Rice, R. E. (2012). Public Communication Campaigns-The American Experience. In Public Communication Campaigns. New York: Sage Publications.

Perdana, A., \& Wildianti, D. (2018). Narasi Kampanye dan Media Sosial dalam Pemilu Presiden dan Wakil Presiden Tahun 2019. Jurnal Bawaslu DKI, 21-39. Retrieved from https://www.researchgate.net/publication/330761813_Narasi_Kampanye_dan_Media_Sosial_dala m_Pemilihan_Presiden_dan_Wakil_Presiden_tahun_2019

Prayoga, F. (2018). Ratna Sarumpaet Dikeroyok, PA 212: Tindakan Biadab dan Pengecut. Retrieved July 20, 2021, from Okezone.com website: https://nasional.okezone.com/read/2018/10/03/337/1958877/ratna-sarumpaet-dikeroyok-pa212-tindakan-biadab-dan-pengecut

Schedler, A. (2002). Elections Without Democracy: The Menu of Manipulation. Journal of Democracy, 13(2), 36-50. https://doi.org/10.1353/jod.2002.0031

Septianto, B. (2019). Andi Arief Unggah Foto Kontainer Surat Suara Bertulis Huruf Kanji. Retrieved July 21, 2021, from Tirto.id website: https://tirto.id/andi-arief-unggah-foto-kontainer-surat-suarabertulis-huruf-kanji-djbs 
Siddiq, T. (2019). Cuitan Andi Arief: Jenderal Kardus hingga 7 Kontainer Surat Suara. Retrieved July 21, 2021, from Tempo.co website: https://nasional.tempo.co/read/1161115/cuitan-andi-ariefjenderal-kardus-hingga-7-kontainer-surat-suara

Simpser, A. (2013). More than Winning - Information and the Consequences of Electoral Manipulation. In Why Governments and Parties Manipulate Elections (pp. 79-120). New York: Cambridge University Press.

Sinaga, C. (2021). Analisis Terhadap Peranan Badan Pengawas Pemilu dalam Menangani Kampanye Hitam pada Pemilihan Umum Presiden Republik Indonesia Tahun 2014 Berdasarkan UndangUndangnomor 15 Tahun 2011 tentang Penyelenggaraan Pemilihan Umum. DHARMASISYA, 1(1), 100-109. Retrieved from https://scholarhub.ui.ac.id/dharmasisya/vol1/iss1/24/

Sirait, F. E. T. (2020). Ujaran Kebencian, Hoax dan Perilaku Memilih (Studi Kasus pada Pemilihan Presiden 2019 di Indonesia). Jurnal Penelitian Politik, 16(2), 179. https://doi.org/10.14203/jpp.v16i2.806

Siregar, F. E. (2019). Mengawasi Media Sosial dalam Proses Pemilu 2019. In Serial Evaluasi Penyelenggaraan Pemilu Serentak 2019: Perihal Penyelenggaraan Kampanye. Jakarta. Retrieved from

https://www.researchgate.net/publication/337705474_Serial_Evaluasi_Penyelenggaraan_Pemilu_ Serentak_2019_Perihal_Penyelenggaraan_Kampanye

Sosiawan, E. A., \& Wibowo, R. (2020). Kontestasi Berita Hoax Pemilu Presiden Tahun 2019 di Media Daring dan Media Sosial. Jurnal Ilmu Komunikasi, 17(2), 133. https://doi.org/10.31315/jik.v17i2.3695

Wardle, C., \& Derakhshan, H. (2017). Information Disorder: Toward an Interdisciplinary Framework for Research and Policy Making. Paris. Retrieved from https://rm.coe.int/information-disordertoward-an-interdisciplinary-framework-for-researc/168076277c 